\title{
Hydrogen Adsorption Characteristics for Zeolite-Y Templated Carbon
}

\author{
Rika Wijiyanti ${ }^{1}$, Triyanda Gunawan ${ }^{1}$, Noor Shawal Nasri ${ }^{2}$, Zulhairun Abdul Karim ${ }^{3,4}$, \\ Ahmad Fauzi Ismail ${ }^{3,4}$, and Nurul Widiastuti1,* \\ ${ }^{1}$ Department of Chemistry, Faculty of Science, Institut Teknologi Sepuluh Nopember, \\ Keputih, Sukolilo, Surabaya 60111, Indonesia \\ ${ }^{2}$ Sustainable Waste-to-Wealth Program, Resource Sustainability Research Alliance, UTM-MPRC Institute for Oil and Gas, \\ Universiti Teknologi Malaysia, 81310 UTM Johor Bahru, Malaysia \\ ${ }^{3}$ Advanced Membrane Technology Research Centre (AMTEC), Universiti Teknologi Malaysia, \\ 81310 UTM Skudai, Johor Darul Ta'zim, Malaysia \\ ${ }^{4}$ Department of Energy Engineering, School of Chemical and Energy Engineering, Universiti Teknologi Malaysia, \\ 81310 UTM Johor Bahru, Johor, Malaysia
}

\author{
*Corresponding author: \\ email:nurul_widiastuti@chem.its.ac.id \\ Received: September 21, 2018 \\ Accepted: January 18, 2019 \\ DOI: $10.22146 /$ ijc. 38978
}

\begin{abstract}
The hydrogen adsorption, kinetic and thermodynamic of adsorption onto the zeolite templated carbon (ZTC) were examined at the temperature range of $30-50{ }^{\circ} \mathrm{C}$ and ambient pressure. The ZTC was prepared from zeolite-Y template and sucrose carbon precursor by impregnation method and showed its specific surface area of $932 \mathrm{~m}^{2} / \mathrm{g}$ as well as $0.97 \mathrm{~cm}^{3} / g$ for total pore volume. Analysis of physical and chemical characteristics for materials were performed using XRD, SEM, TEM and $\mathrm{N}_{2}$ isotherm. The results indicated that the ZTC has some ordered network structure of carbon and also exhibits the formation of the carbon layer outside the zeolite micropore. We observed the ZTC for hydrogen adsorption both gravimetric and volumetric method up to 1.72 and $1.16 \mathrm{wt} . \%$ at the lowest temperature, respectively. The kinetic process at all studied temperature was best approximated by the pseudo-second-order kinetic model. The aspects of thermodynamic such as heat of adsorption and the entropy change were $-14.41 \mathrm{~kJ} / \mathrm{mol}$ and $-40.93 \mathrm{~J} / \mathrm{K} \mathrm{mol}$, respectively. Both values were negative, indicating an exothermic reaction and low disorder at the hydrogen and ZTC interface when the adsorption process took place. Meanwhile, the enthalpy change value exhibits a characteristic of a physical process. The Gibbs energy change calculated at 30, 40 and $50{ }^{\circ} \mathrm{C}$ were $-1.99,-1.59$ and $-1.19 \mathrm{~kJ} / \mathrm{mol}$, respectively, indicating a spontaneous adsorption process.
\end{abstract}

Keywords: zeolite-Y templated carbon; hydrogen adsorption; adsorption kinetics; thermodynamics

\section{- INTRODUCTION}

Hydrogen is a clean alternative fuel as its main product from the burning process is only water. Moreover, hydrogen is the highest element up to $75 \%$ from the normal mass of earth, and thus it can be employed as prosperous sources for hydrogen fuel generation [1]. Hydrogen also has almost three times higher of energy content $(33 \mathrm{kWh} / \mathrm{kg})$ as compared to the gasoline (12 kWh/kg) [2]. Therefore, research efforts have been actively pursued to utilize hydrogen for fuel cell vehicles.

In addition to high energy density and its availability, the hydrogen storage system including volume, weight, safety and the reversibility of hydrogen adsorption rate should be concerned [2]. The conventional hydrogen storage systems are compressed hydrogen tank or liquefied hydrogen. However, it has a 
safety risk due to high pressure and low temperature system [3]. More recently, the main concern of research has been focused on solid state porous materials to meet the United States Department of Energy (DOE) onboard storage target due to its high densities of both gravimetric and volumetric at lower pressure. The DOE ultimate targets for storage density at or close to ambient condition are 7.6 wt.\% (gravimetrically) and $0.07 \mathrm{~kg} / \mathrm{dm}^{3}$ (volumetrically), respectively [1-2] Recently, hydrogen storage system in solid state porous materials, for instance, carbons, zeolites or metal organic frameworks, is attractive because of their advantages such as fast adsorption kinetics, high cyclability, and reversibility of hydrogen uptake and release [4-5].

Among of these porous materials, carbon-based materials received a lot of interest since it has a high gravimetric and volumetric densities, high thermal and good chemical stability [4,6-7]. The amount of hydrogen uptake in carbon materials reached up to $11 \mathrm{wt} . \%$ [8]. Hydrogen can be adsorbed reversibly in the carbons by physisorption process at ambient temperature. Based on physisorption, the physical properties including pore size, specific surface area, and micropore volume seriously affect the hydrogen capacity [9-11]. Carbons possess some superiorities such as a large surface area up to $3500 \mathrm{~m}^{2} / \mathrm{g}$, lightweight and easy to modify the pore structure [1]. Yet, the main drawback for carbon materials in the storage system is its wide pore size distribution $[7,10]$. Hence, the pore structure of carbons should be modified in order to enhance adsorption capacities. The templated method could be an excellent way to gain a new carbon porous materials with a large surface area up to $4000 \mathrm{~m}^{2} / \mathrm{g}$, and controlled porosity reached $1.6 \mathrm{~cm}^{3} / \mathrm{g}$ for hydrogen storage purpose. Yang et al. [12] reported that templated carbon exhibited the highest storage capacity than the other materials, such as zeolites, carbon nanotubes, metal organic frameworks, and organic microporous polymer. It is found that a high microporosity and specific surface area of carbons provide a linear relation with hydrogen adsorption capacity [12-13].

The choice of materials such as carbon precursor and the inorganic template is being a major factor contributing to the carbon structure [7,14-15]. The inorganic templates widely used for templated carbon include zeolite, silica, Metal Organic Framework (MOF) and layered clay. Zeolite and MOF used as template result in microporous carbon with large surface area and well-defined porous structure. However, the synthesis of MOF template needs a lot of time and results in low yield. On the contrary, a silica template is employed to prepare mesoporous carbon. Also, the resulting carbon with low surface area and high graphitization degree are obtained by using a layered clay template. However, a porous material is suited for application in gas adsorption; thus, zeolite exhibits outstanding potential template material to fabricate microporous carbon. There are several studies of templated carbon materials synthesized using various carbon sources or different zeolite type templates. Zeolites have ordered pores and channels; therefore they can be more appropriate to synthesize carbon with micropore structure for hydrogen storage purpose $[11,16]$.

Kyotani et al. [15] synthesized templated carbon via a combination of two methods (furfuryl alcohol by impregnation and propylene via CVD) using a different type of zeolite (zeolite-Y, L, $\beta$, mordenite, and ZSM-5) as templates. The regularity of the carbon using zeolite-Y was much better than other zeolites such as superior surface area $\left(2750 \mathrm{~m}^{2} / \mathrm{g}\right)$ as well as perfect microporosity $\left(1.5 \mathrm{~cm}^{3} / \mathrm{g}\right)$. Templated carbons using different zeolite (13-X and $\mathrm{Y}$ ) and acetonitrile have also been prepared by Yang et al. [17]. Carbon with zeolite-Y template exhibited $21 \%$ larger surface area and $263 \%$ higher micropore volume than that of zeolite-13X. As reported by Johnson et al. [18], pyrolytic carbon synthesized in the channel of zeolite-Y was preferable since it has three dimensionally interconnected micropore structure. On the other hand, Yang et al. [17] also prepared carbon material using different carbon sources (acetonitrile or ethylene) and zeolite- $Y$ as hard template. They investigated that carbon with acetonitrile and zeolite-Y had a surface area ranging from 1910 to $1920 \mathrm{~m}^{2} / \mathrm{g}$, micropore volume of 0.1 to $0.5 \mathrm{~cm}^{3} / \mathrm{g}$ and significantly obtained ordered carbon structure. When ethylene was employed as carbon source, the surface area and micropore volume of the ZTC reached to $1300 \mathrm{~m}^{2} / \mathrm{g}$ and 
$0.2 \mathrm{~cm}^{3} / \mathrm{g}$, respectively, obtained ordered not only carbon but also a high amount of graphitization. It is believed that hydrogen uptake capacity linearly relates to the surface area and microporosity. Therefore, it can be controlled by material selection.

In addition to the porosity of materials, hydrogen uptake in the adsorptive system is directly related to the operation conditions [6]. For hydrogen storage system, carbon materials would be more appropriate when they could adsorp at or near to room condition, as described by the DOE [1]. Several researchers have reported the hydrogen storage capacity of ZTC at a temperature of $-196{ }^{\circ} \mathrm{C}[11-12,17,19]$. Hydrogen uptake capacity at ambient temperature $\left(30{ }^{\circ} \mathrm{C}\right)$ has been reported by Nishihara et al. [20] for zeolite templated carbon. They investigated the small amount of hydrogen sorption in the range of $0.41-0.87$ wt.\% at high pressure of 98 bar. Whereas, the hydrogen uptake capacity on SWNTs at ambient pressure ( 1 bar) and temperature of $<40{ }^{\circ} \mathrm{C}$ was reported by Hirscher et al. [21], and the capacity obtained was 1.8 wt.\%. Moreover, the ZTC's performance at or close to room temperature and pressure is still unknown. Therefore, in this work, we examine the hydrogen uptake performance at or close to ambient temperature and pressure.

In addition, to provide an understanding of the adsorption mechanism, the kinetic study of hydrogen adsorption would be necessary [22]. Zamora et al. [22] studied the kinetic hydrogen adsorption on the composite comprising TiNT decorated with $\mathrm{Cd}_{3} \mathrm{Fe}^{\text {III }}$ by implementing the intra-particle diffusion model. Furthermore, thermodynamic aspects such as enthalpy, entropy, and Gibbs free energy are other main factors to be considered in the adsorption process in order to determine the feasibility of ZTC for $\mathrm{H}_{2}$ storage purpose. The change of enthalpy provides the information of binding strength between gas molecules and adsorbent and to explain the influence of temperature in the adsorption process [4]. Based on DOE's target, the desired enthalpy value of hydrogen uptake under room conditions is between 15 to $25 \mathrm{~kJ} \mathrm{~mol}^{-1}$ for reversibly hydrogen storage [23]. However, the standard heat of hydrogen adsorption on carbon (active carbon or carbon nanotube) is only $6 \mathrm{~kJ} / \mathrm{mol}$, and it is too weak to adsorp hydrogen at ambient temperature which was investigated by Myers et al. [23].

The goals of the present work were to report the amount of hydrogen adsorption on templated carbon at or near to room temperature $\left(30,40\right.$ and $\left.50{ }^{\circ} \mathrm{C}\right)$ and ambient pressure by both gravimetric and volumetric methods. Templated carbon was prepared by utilizing zeolite-Y template with sucrose as a carbon precursor by a simple impregnation method. Sucrose is a small organic molecule and contains high carbon yield which is widely used as a precursor to prepare microporous carbon [12,15,23]. Most of the experiment has been conducted on hydrogen storage materials, yet the kinetic and thermodynamic studies are scarce in this field. In this investigation, the kinetic study was analyzed in terms of the pseudo-first and second order as well as the intraparticle diffusion model to provide deeper insight for mechanisms of hydrogen adsorption. The thermodynamic aspects including the heat of adsorption, the Gibbs energy, and the entropy change were also determined in order to evaluate the feasibility of templated carbon as storage system of hydrogen.

\section{- EXPERIMENTAL SECTION}

\section{Materials}

The materials used were sodium aluminate powder $\left(\mathrm{NaAlO}_{2}, 95.45 \%\right)$ and sodium silicate $\left(\mathrm{Na}_{2} \mathrm{SiO}_{3}\right)$ provided by Sigma Aldrich, sodium hydroxide pellet $(\mathrm{NaOH})$ purchased from Merck, sucrose $\left(\mathrm{C}_{12} \mathrm{H}_{22} \mathrm{O}_{11} 98 \%\right.$ Fluka), sulfuric acid $\left(\mathrm{H}_{2} \mathrm{SO}_{4} 98 \%\right.$ pa), fluoric acid (HF, $48 \%)$ provided by Merck, hydrochloric acid $(\mathrm{HCl}, 37 \%$ SAP), deionized water, ultra-high purity $\mathrm{N}_{2}$ (99.99\%) and $\mathrm{H}_{2}$ gas $(99.99 \%)$.

\section{Instrumentation}

X-Ray Diffraction (XRD) diffractograms were recorded by Expert PAN Analytical using radiation of $\mathrm{CuKa}(\lambda=0.154 \mathrm{~nm}$ at $40 \mathrm{kV}$ and $30 \mathrm{~mA})$. To identify the crystal phase and crystallinity of the ZTC, the X-ray diffractograms were determined in the range of $3-50^{\circ}$. Physical properties of the zeolite-Y and ZTC were determined via $\mathrm{N}_{2}$ sorption at $-196{ }^{\circ} \mathrm{C}$ using a 
Quantachrome Autosorb-1. The powders were degassed at $250{ }^{\circ} \mathrm{C}$ in vacuum for overnight prior to the analysis. The Brunauer-Emmett-Teller method at $\mathrm{P} / \mathrm{P}_{0}$ between 0.04 to 0.31 was used to determine the specific surface area. While the total pore volume $\left(\mathrm{V}_{\mathrm{t}}\right)$ of the sample was estimated from the amount of $\mathrm{N}_{2}$ adsorbed at $\mathrm{P} / \mathrm{P}_{0} 0.993$, and the micropore volume was calculated using Saito Foley (SF) method. Pore size distribution (PSD) of samples was determined from the $\mathrm{N}_{2}$ isotherm using Horvath-Kawazoe (HK) theory with the assumption of slit pore shape and Barrett-Joyner-Halenda (BJH) method. The morphology analysis for zeolite-Y and ZTC was performed by scanning electron microscope (SEM, ZEISS EVO MA 10). Transmission Electron Micrographs were collected with $\mathrm{H} 9500$ at $200 \mathrm{kV}$ acceleration voltage to identify the structure of samples.

\section{Procedure}

\section{Synthesis of zeolite-Y template}

Zeolite-Y was synthesized using sodium aluminate (Sigma-Aldrich, 13404-5KG-R), sodium silicate (SigmaAldrich, 338443-3L), NaOH (99\% pa, Merck, 011-022-006) and deionized water as source materials. Zeolite-Y was made through three steps: seed gel, feedstock gel and overall gel [24]. The molar composition of seed gel was
$10.67 \mathrm{Na}_{2} \mathrm{O}: 1 \mathrm{Al}_{2} \mathrm{O}_{3}: 10 \mathrm{SiO}_{2}: 180 \mathrm{H}_{2} \mathrm{O}$ and the molar ratio of feedstock to seed gel was 18:1. The adding of seed gel to feedstock gel formed an overall gel and subsequently subjected to the hydrothermal process at $100^{\circ} \mathrm{C}$ for $7 \mathrm{~h}$. The sample obtained was flowed by deionized water to get neutral $\mathrm{pH}$ of filtrate and subsequently dried at $110^{\circ} \mathrm{C}$ for $12 \mathrm{~h}$. Prior further treatment, the zeolite-Y sample was pretreated at $200^{\circ} \mathrm{C}$ for $4 \mathrm{~h}$ in flowing nitrogen.

\section{Synthesis of zeolite-Y templated carbon (ZTC)}

The ZTC was synthesized from zeolite-Y template and sucrose (98\% Fluka) by impregnation method as presented in Fig. 1. The detailed procedure of ZTC synthesis is described as follows:

The sucrose was dissolved in $0.35 \mathrm{M} \mathrm{H}_{2} \mathrm{SO}_{4}$ at room temperature, then the pretreated zeolite- $\mathrm{Y}$ was added to this clear solution. Based on our previous study, the optimum ratio of sucrose to zeolite-Y was 1.25 (wt.\%). The solution was stirred for $72 \mathrm{~h}$ at ambient temperature and then filtered, followed by carbonization treatment in a tubular furnace under $\mathrm{N}_{2}$ atmosphere. The carbonization process was conducted to the fixed temperature of $800^{\circ} \mathrm{C}$ for $4 \mathrm{~h}$ dwelling time by a heating rate of $2{ }^{\circ} \mathrm{C} / \mathrm{min}$ according to the best result in our preceding study. The resulted of the black composite was

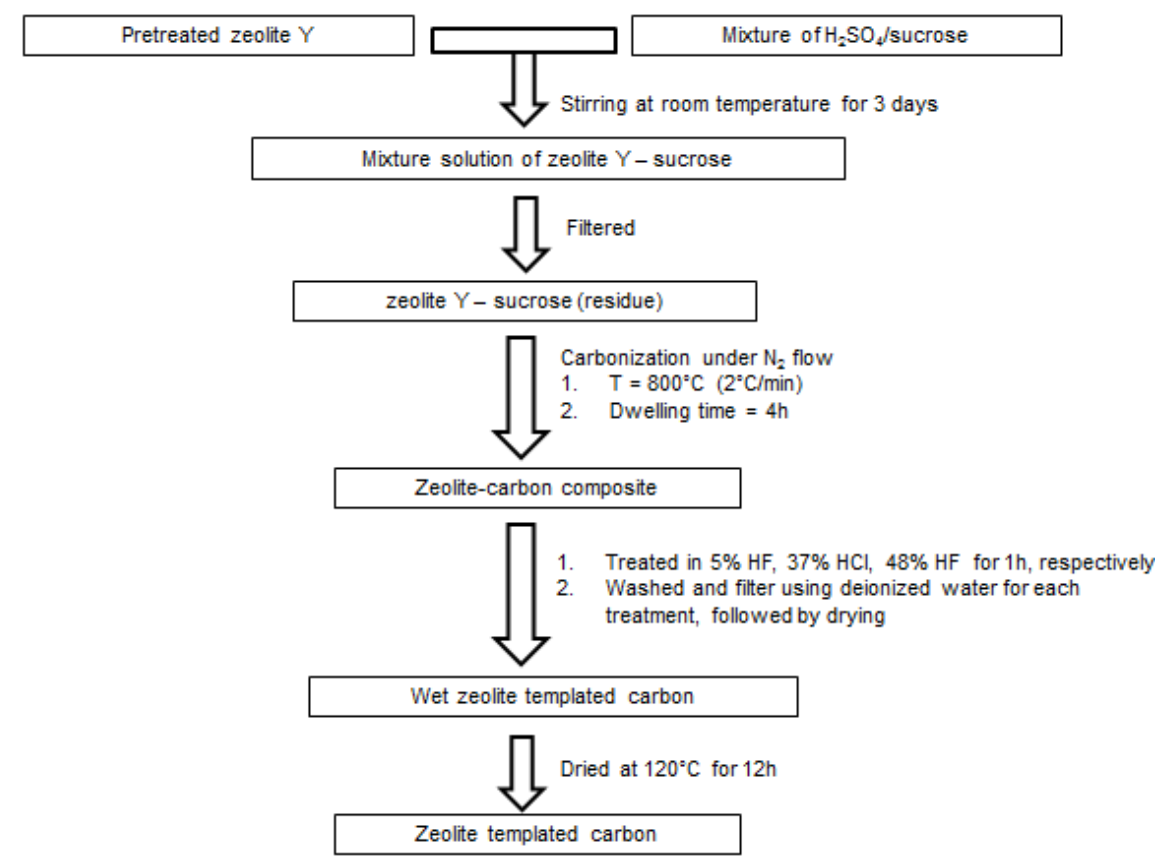

Fig 1. Schematic of preparation procedure of zeolite templated carbon 
cooled until room temperature using $\mathrm{N}_{2}$ stream and then washed by three steps of acid to remove the zeolite-Y template. (1) The composite was treated with $5 \% \mathrm{HF}$ solution at ambient temperature for $1 \mathrm{~h}$ to break the $\mathrm{Si}$-O$\mathrm{Al}$ bond of template. The sample was washed using deionized water insistently to obtain a neutral $\mathrm{pH}$ of filtrate and dried at $110^{\circ} \mathrm{C}$ for $12 \mathrm{~h}$. (2) Then, the sample was immersed in $37 \% \mathrm{HCl}$ via reflux at $60^{\circ} \mathrm{C}$ for $1 \mathrm{~h}$ to remove aluminum of zeolite framework, subsequently filtered and washed by deionized water and followed by drying for $12 \mathrm{~h}$ at temperature of $120^{\circ} \mathrm{C}$ (3). In addition, the solid sample was soaked in $48 \%$ HF solution for $1 \mathrm{~h}$ for removal of silica content from zeolite template. The sample was then washed by deionized water to get a neutral $\mathrm{pH}$ of filtrate, then a residue of sample known as zeolite templated carbon (ZTC) was dried during $12 \mathrm{~h}$ at $120^{\circ} \mathrm{C}$.

\section{Hydrogen adsorption test}

The amounts of hydrogen uptake on the ZTC were determined in a custom-fabricated packed-bed adsorption system using volumetric, pressure and temperature measurement in equilibrium conditions by static adsorption procedure adopted from other studies [25-26]. The fixed bed adsorption unit was used at static mode to collect single gas adsorption data presented in Fig. 2. The adsorption apparatus was made using stainless steel tubing and proper Swagelok fittings. The cell was placed in a well-insulated furnace to control the temperature, pressure, and volume in equilibrium state for single gas uptake. The hydrogen sorption capacity was measured at different temperature of 30,40 and $50^{\circ} \mathrm{C}$. Prior to the adsorption test, the adsorbent was dried in-situ at $105^{\circ} \mathrm{C}$ for $1 \mathrm{~h}$. The gas presented in the adsorption cell was purged using a vacuum pump before to start the test. Digital pressure transducer and thermocouple put axially in the middle of the adsorption cell to observe the temperature of cell continuously.

An adsorption cell was filled with $1.5018 \mathrm{~g}$ adsorbent. The adsorption was conducted at a temperature of 30,40 and $50{ }^{\circ} \mathrm{C}\left( \pm 3{ }^{\circ} \mathrm{C}\right)$ using the single sample weight. Prior passing the hydrogen to the adsorption cell, the gas pressure of the loading cell was set at the equilibrium of 2 bar as an initial value, and then gas

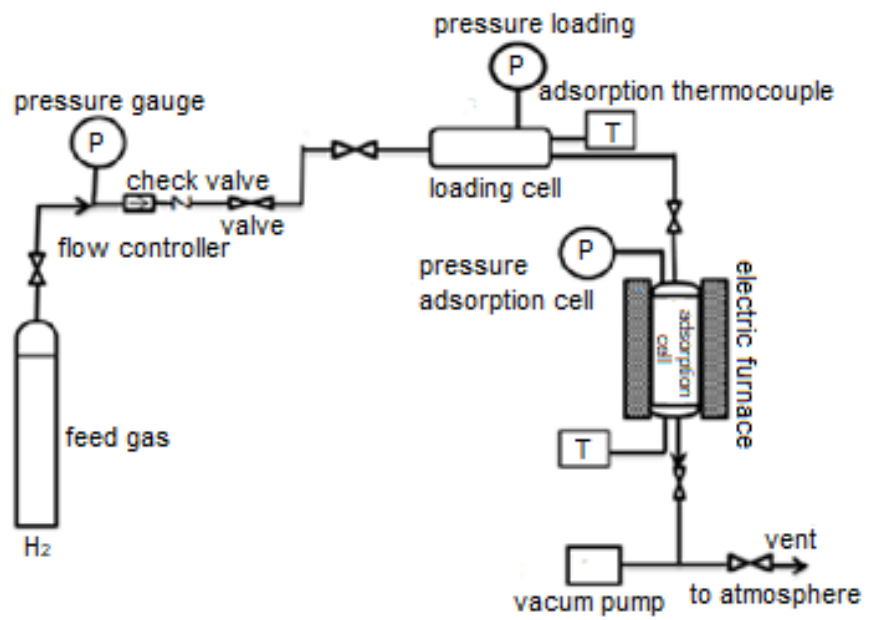

Fig 2. Schematic diagram of the fixed bed volumetric adsorption test rig

was flowed into the adsorption cell by opening the connecting valve at the target temperature. Pressure and temperature measurement of both cells were monitored to obtain the amount of hydrogen adsorbed. The pressure of loading $\left(\mathrm{P}_{\mathrm{l}}\right)$ and adsorption $\left(\mathrm{P}_{\mathrm{a}}\right)$ cell measured were recorded until the equilibrium conditions were obtained. Adsorption equilibrium is achieved when the operating conditions (temperature and pressure) were constant. The amount of hydrogen uptake was determined using the mass balance through both cells in terms of temperature and pressure recorded at initial and equilibrium condition, according to the Eq. (1) [26]:

$\mathrm{q}_{\mathrm{e}}=\frac{1}{\mathrm{~m}}\left[\frac{\mathrm{V}_{\mathrm{v}}}{\mathrm{R}}\left(\left|\frac{\mathrm{P}}{\mathrm{ZT}}\right|_{\mathrm{i}}-\left|\frac{\mathrm{P}}{\mathrm{ZT}}\right|_{\mathrm{eq}}\right)_{\mathrm{a}}+\frac{\mathrm{V}_{\mathrm{l}}}{\mathrm{R}}\left(\left|\frac{\mathrm{P}}{\mathrm{ZT}}\right|_{\mathrm{i}}-\left|\frac{\mathrm{P}}{\mathrm{ZT}}\right|_{\mathrm{eq}}\right)_{1}\right]$

in which the pressure is $P$, the temperature is $T$, the gas constant is $\mathrm{R}$, the adsorption cell is a, the adsorption cell volume is $V_{v}$, the compressibility factor is $Z$, the loading cell is 1 , the loading cell volume is $\mathrm{V}_{\mathrm{l}}$, $\mathrm{i}$ and eq represent the initial and equilibrium state, respectively; and the adsorbent mass is $\mathrm{m}$.

The hydrogen sorption was also performed using the gravimetric method (Fig. 3) as follows. Prior to the experiment, the ZTC was dried at $105^{\circ} \mathrm{C}$ during $1 \mathrm{~h}$ and then degassed by a heating rate of $3{ }^{\circ} \mathrm{C} / \mathrm{min}$ to $350^{\circ} \mathrm{C}$ for $3 \mathrm{~h}$. The pretreated sample $(0.3 \mathrm{~g})$ as initial mass was then cooled to the adsorption temperature. The adsorption process was conducted over the temperature 


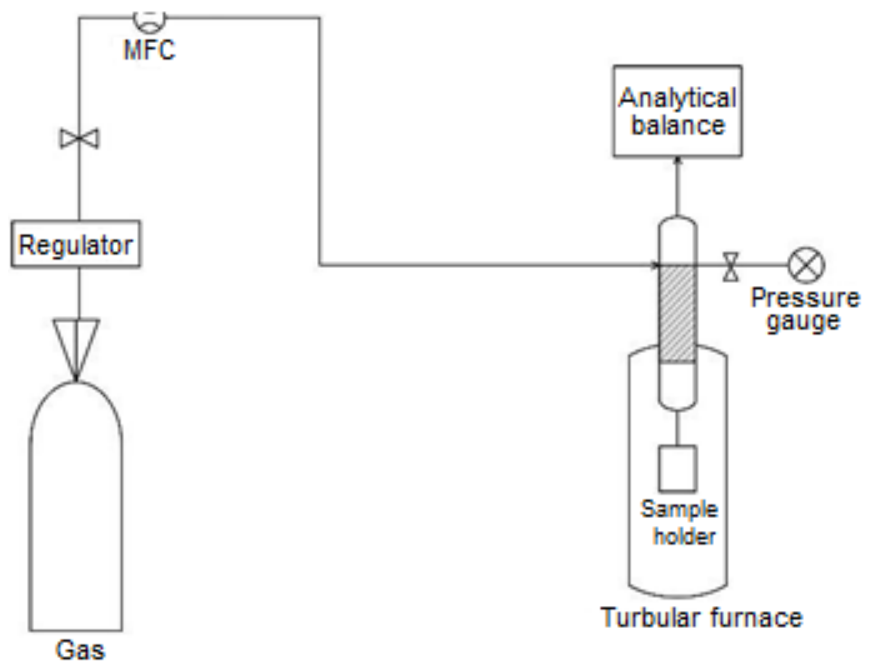

Fig 3. Schematic diagram of gravimetric adsorption test

of $30,40,50{ }^{\circ} \mathrm{C}$ and ambient pressure. Adsorption measurement was started via initiating the hydrogen flow rate of $20 \mathrm{~mL} / \mathrm{min}$, then evaluated within a few minutes to achieve sorption equilibrium of ZTC and recorded as mass at equilibrium state. The capacity of hydrogen uptake was obtained from the mass balance through the adsorption cell, according to the Eq. (2):

$\% \mathrm{wt}=\frac{\mathrm{m}_{\mathrm{t}}-\mathrm{m}_{0}}{\mathrm{~m}_{0}} \times 100 \%$

where $\mathrm{m}_{\mathrm{t}}$ is the mass at $\mathrm{t}$ min and $\mathrm{m}_{0}$ is the initial mass.

\section{Kinetics data analysis}

Adsorption kinetic models of the pseudo first order, pseudo-second order, and intraparticle diffusion were determined to investigate of hydrogen sorption mechanism onto ZTC [25,27]. The pseudo first-order model is generally applied for the adsorption process, expressed by Eq. (3).

$\frac{\mathrm{dq}_{\mathrm{t}}}{\mathrm{dt}}=\mathrm{k}_{\mathrm{f}}\left(\mathrm{q}_{\mathrm{e}}-\mathrm{q}_{\mathrm{t}}\right)$

where $\mathrm{q}_{\mathrm{t}}(\mathrm{mmol} / \mathrm{g})$ is the amount of hydrogen adsorbed at time $\mathrm{t}(\mathrm{min}), \mathrm{q}_{\mathrm{e}}(\mathrm{mmol} / \mathrm{g})$ is the adsorption capacity at equilibrium state, $\mathrm{k}_{\mathrm{f}}\left(\mathrm{min}^{-1}\right)$ is the rate constant of pseudofirst order. After integrating at boundary conditions $\mathrm{q}_{\mathrm{t}}=$ 0 at $\mathrm{t}=0$ and $\mathrm{q}_{\mathrm{t}}=\mathrm{q}_{\mathrm{t}}$ at $\mathrm{t}=\mathrm{t}$, yields the Eq. (4).

$\ln \left(\mathrm{q}_{\mathrm{e}}-\mathrm{q}_{\mathrm{t}}\right)=\ln \mathrm{q}_{\mathrm{e}}-\mathrm{k}_{1} \mathrm{t}$

The pseudo second-order model is defined in Eq. (5).

$\frac{\mathrm{dq}_{\mathrm{t}}}{\mathrm{dt}}=\mathrm{k}_{\mathrm{s}}\left(\mathrm{q}_{\mathrm{e}}-\mathrm{q}_{\mathrm{t}}\right)^{2}$ in which $\mathrm{k}_{\mathrm{s}}\left(\mathrm{g} \mathrm{mg}^{-1} \mathrm{~min}^{-1}\right)$ is pseudo-second-order rate constant. This can be integrated by using the initial conditions of $\mathrm{q}_{\mathrm{t}}=0$ at $\mathrm{t}=0$ and $\mathrm{q}_{\mathrm{t}}=\mathrm{q}_{\mathrm{t}}$ at $\mathrm{t}=\mathrm{t}$ and the equation above is a linear equation:

$\frac{\mathrm{t}}{\mathrm{q}_{\mathrm{t}}}=\frac{1}{\mathrm{k}_{\mathrm{s}} \mathrm{q}_{\mathrm{e}}^{2}}+\frac{1}{\mathrm{q}_{\mathrm{e}}} \mathrm{t}$

A straight line with slope $1 / \mathrm{q}$ will be obtained from a plot between $t / \mathrm{q}_{t}$ and $\mathrm{t}$ when adsorption mechanism fits this kinetic model.

The equation of intra-particle diffusion is given as follows:

$\mathrm{q}_{\mathrm{t}}=\mathrm{k}_{\mathrm{id}} \mathrm{t}^{\mathrm{1} / 2}+\mathrm{C}$

where $\mathrm{k}_{\mathrm{id}}\left(\mathrm{mmol} \mathrm{g}^{-1} \mathrm{~min}^{-0.5}\right)$ is the rate constant, $\mathrm{t}$ is time (min). The values of $k_{\mathrm{id}}$ and $\mathrm{C}$ can be calculated experimentally through the slope and intercept of $\mathrm{q}_{t}$ versus $\mathrm{t}^{1 / 2}$, respectively. An intercept value of $\mathrm{C}$ indicates the thickness of the boundary layer, in which the bigger value of $\mathrm{C}$, the greater effect for the boundary layer.

\section{Thermodynamic study}

The adsorption enthalpy $(\Delta \mathrm{H})$ and entropy $\left(\Delta \mathrm{S}_{\mathrm{H}}\right)$ change of hydrogen adsorption are calculated from the graph between ln P versus 1/T based on the Van't Hoff equation [22]:

$\ln \mathrm{P}=2\left(\frac{\Delta \mathrm{H}}{\mathrm{RT}}-\frac{\Delta \mathrm{S}_{\mathrm{H}}}{\mathrm{R}}\right)$

in which $\Delta \mathrm{H}$ in $\mathrm{kJ} \mathrm{mol}^{-1}$ and $\Delta \mathrm{S}_{\mathrm{H}}$ in $\mathrm{J} \mathrm{K}^{-1} \mathrm{~mol}^{-1}$. $\mathrm{T}$ is temperature $(\mathrm{K}), \mathrm{p}$ is pressure at constant equilibrium uptake (bar), and $\mathrm{R}$ is the gas constant $\left(\mathrm{J} \mathrm{mol}^{-1} \mathrm{~K}^{-1}\right)$. The slopes of the straight line give the value of $2 \Delta \mathrm{H} / \mathrm{R}$, and the intercepts give the value of $-\left(2 \Delta \mathrm{S}_{\mathrm{H}} / \mathrm{R}\right)$.

The Gibbs energy $\left(\Delta \mathrm{G}_{\text {ads }}\right)$ value is commonly calculated by the following equation:

$\Delta \mathrm{G}_{\mathrm{ads}}=\Delta \mathrm{H}-\mathrm{T} \Delta \mathrm{S}_{\mathrm{H}}$

in which $\Delta \mathrm{G}_{\mathrm{ads}}$ in $\mathrm{kJ} \mathrm{mol}^{-1}$.

\section{- RESULTS AND DISCUSSION}

\section{XRD Analysis}

The X-ray diffraction patterns of zeolite standard and zeolite-Y obtained are presented in Fig. 4(a) and (b), respectively. It could be seen that the diffraction patterns and intensities for zeolite-Y obtained were similar to the standard data of JCPDS No.: 39-1380. This clearly 
indicated that the zeolite- $\mathrm{Y}$ prepared using $\mathrm{NaOH}$ $\mathrm{NaAlO}_{2}-\mathrm{Na}_{2} \mathrm{SiO}_{3}-\mathrm{H}_{2} \mathrm{O}$ system was successfully formed. These peak patterns have still appeared in the diffraction peaks for composite sample, but these peaks slightly shifted to the higher angle, as shown in Fig. 4(c). The shift of the peaks might be due to the shrinkage of the zeolite framework after carbonization process [28]. Furthermore, these diffraction peak intensities were also decreased as compared to the zeolite- $Y$, suggesting that the carbon might be in the surface of the template [29].

The peak patterns of the ZTC obtained are demonstrated in Fig. 4(d). This sample exhibited XRD peak around $6.05^{\circ}$, close to those of parent zeolite-Y $\left(\sim 6.14^{\circ}\right)$. This indicated that there was a regular ordering of pore structure for carbon sample, corresponding to the (111) peak of template $[11,30]$. Furthermore, a broad peak centered around $2 \theta=25^{\circ}$ was appeared with low relative intensity and also observed in zeolite templated carbon by other studies $[12,30]$. This peak suggests the formation of amorphous graphitic carbon (002) plane due to the stacking graphene nanosheets outside zeolite micropore. This stacking graphene may be formed due to the presence of carbon deposition in the pore mouth of zeolite upon the carbonization process, therefore, obstructing access of sucrose into the zeolite [11]. It can be concluded that ZTC in this study kept some pore structure ordering of zeolite and also produced the graphitic carbon.

\section{SEM and TEM Observation}

The SEM analysis for zeolite-Y and ZTC were presented in Fig. 5(a) and (b), respectively. Zeolite-Y image as shown in Fig. 5(a) exhibited a clear crystal face from each particle. The shape morphology for zeolite-Y was partially replicated in the ZTC sample (Fig. 5(b)), indicating that the ZTC did not fully retain the morphology of the template. A few aggregates of the amorphous graphitic structure was observed in the ZTC sample, which was in accordance with the XRD result. The particle size of ZTC was up to $500 \mathrm{~nm}$, smaller as compared to the zeolite-Y template due to the particle shrinkage during the carbonization process. The particle shrinkage might be due to the shrinkage of the zeolite template as confirmed by the XRD observation [28].

The TEM images for the zeolite-Y, zeolite-carbon composite and ZTC samples are shown in Fig. 6. The octahedral morphology for zeolite-Y is similar to the

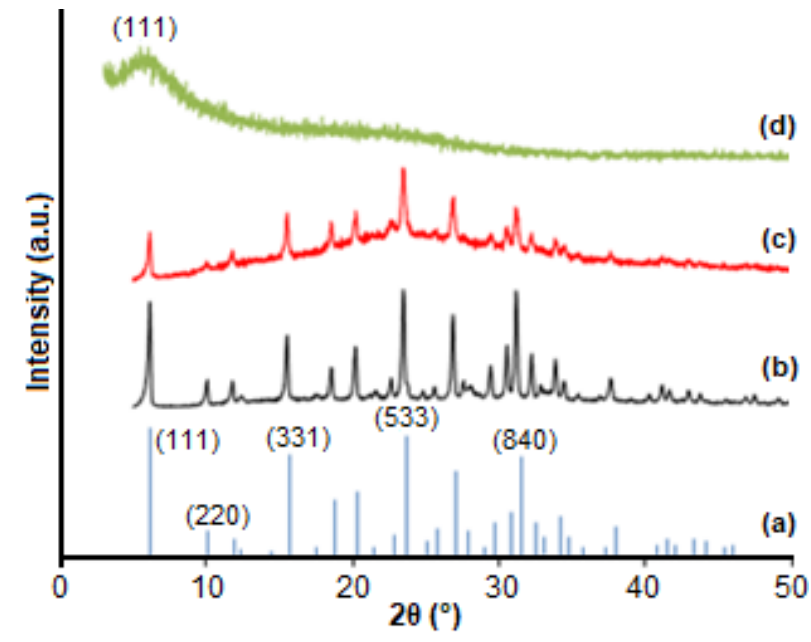

Fig 4. XRD pattern of (a) standard JCPDS No. 39-1380, (b) as-synthesized zeolite-Y, (c) zeolite-carbon composite, and (d) zeolite templated carbon

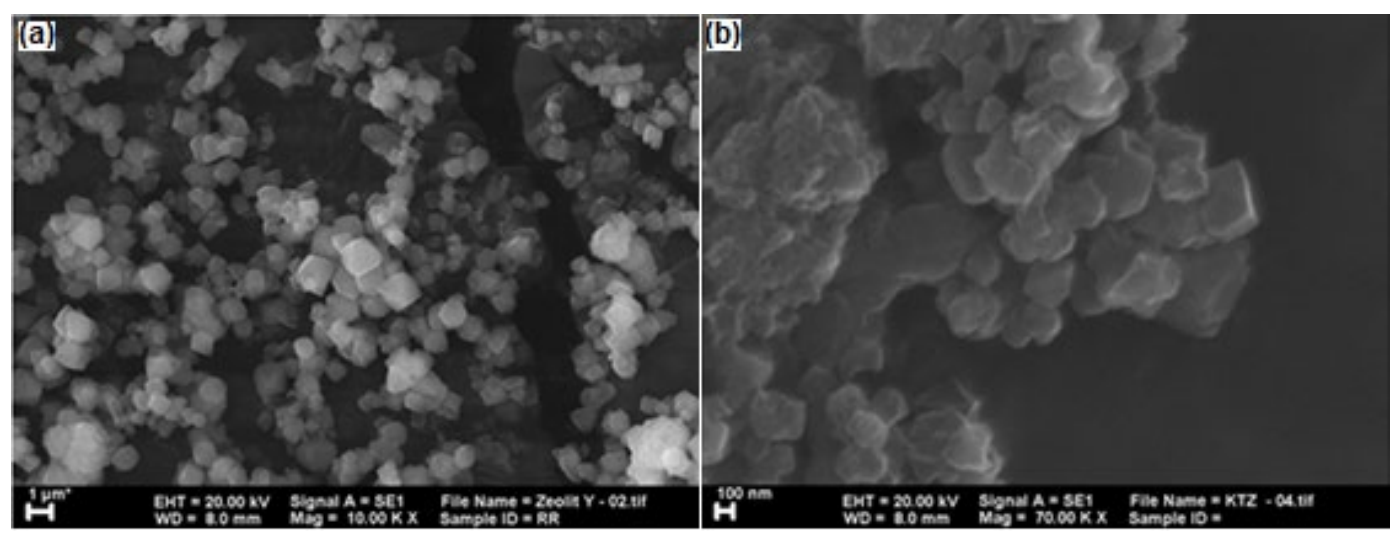

Fig 5. The SEM images of (a) zeolite-Y and (b) ZTC 

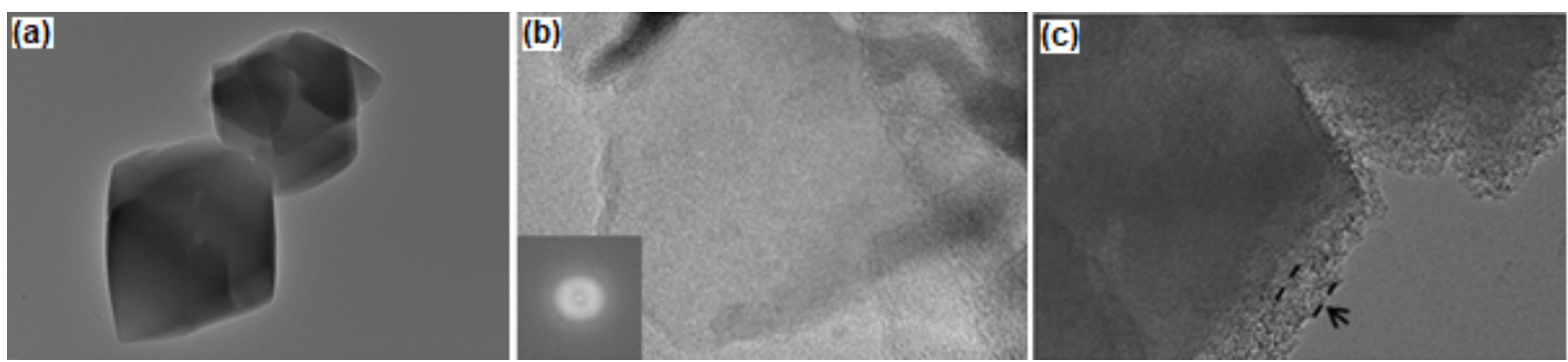

Fig 6. The TEM images of (a) zeolite-Y, (b) ZTC (the inset corresponds to electron diffraction pattern taken from this image), and (c) ZTC (the region indicated by an arrow are the dense amorphous carbon layers deposited in the external surface of zeolite micropore

SEM images in Fig. 5 with the measured particle size up to $1000 \mathrm{~nm}$. However, a diffused ring in the SAED pattern of ZTC (inset of Fig. 6(c)) suggests that the amorphous structure is observed, which is similar to XRD and SEM analysis [31]. The diffraction ring can be attributed as a thin and dense graphitic carbon, indicating carbon (002) layer around the external surface of zeolite-Y particles (Fig. 6(c)) [32-33]. The graphitic shell thickness was ranging from 15-50 $\mathrm{nm}$ (black arrow region).
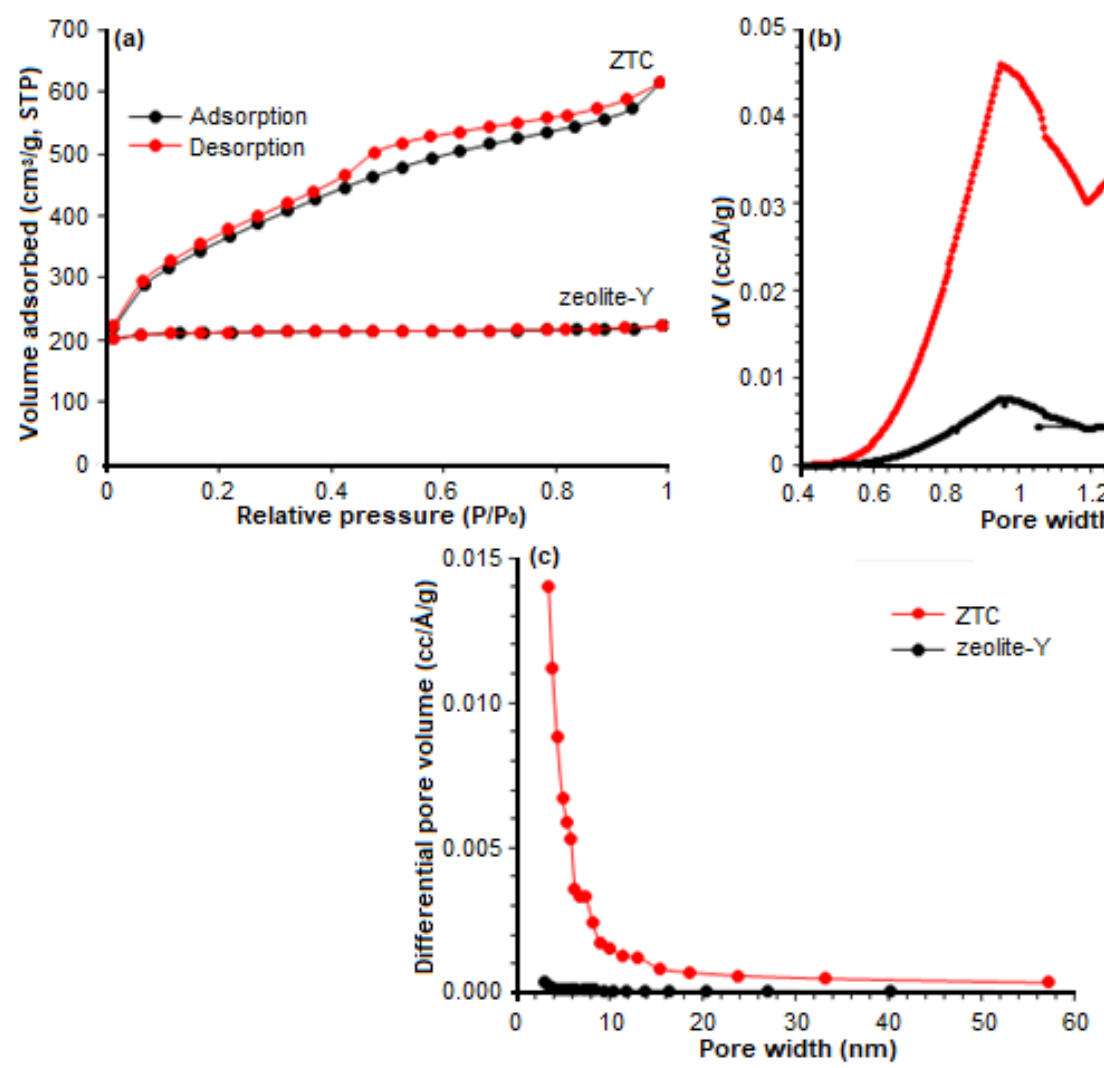

Fig 7. The $\mathrm{N}_{2}$ adsorption-desorption isotherm on the zeolite-Y template and ZTC at $-196{ }^{\circ} \mathrm{C}$ (a) PSD analyzed using HK method (b) and BJH method (c) of the prepared zeolite-Y and ZTC

\section{Textural Properties of the Sample}

The textural properties of zeolite-Y and ZTC such as BET surface area, micropore, and mesopore volume were obtained using their adsorption isotherm (Fig. $7(\mathrm{a})$ ) and the values were presented in Table 1. As seen from the figure, the adsorption isotherm for the zeolite$\mathrm{Y}$ template was a typical type I isotherm, indicating a microporous material for zeolite sample. On the other hand, the existence of desorption hysteresis in the ZTC

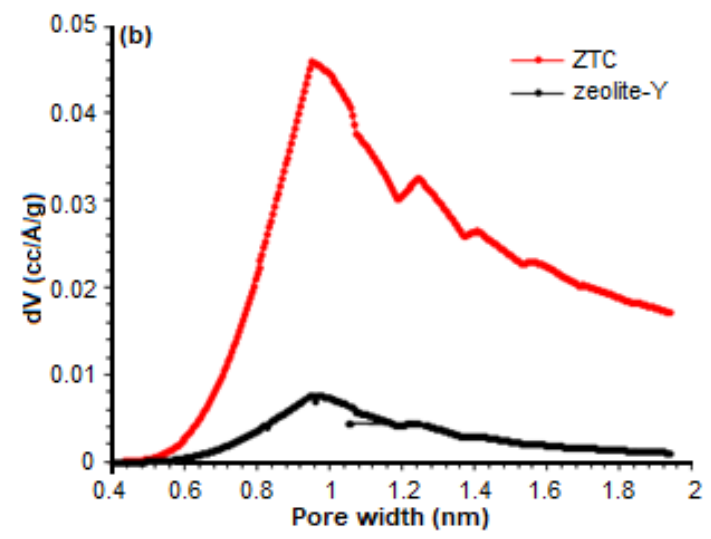


Table1. Textural properties of the resultant zeolite-Y and ZTC

\begin{tabular}{lccc}
\hline Sample & $\begin{array}{c}\text { BET surface } \\
\text { area }\left(\mathrm{m}^{2} / \mathrm{g}\right)\end{array}$ & $\begin{array}{c}\text { Total pore } \\
\text { volume }\left(\mathrm{cm}^{3} / \mathrm{g}\right)\end{array}$ & $\begin{array}{c}\text { Micropore } \\
\text { volume }\left(\mathrm{cm}^{3} / \mathrm{g}\right)\end{array}$ \\
\hline Zeolite-Y & 686 & 0.40 & 0.34 \\
ZTC & 932 & 0.97 & 0.30 \\
\hline
\end{tabular}

sample suggested the mesopores characteristic. The mesopore structure might be attributed by (1) the unfilled region of carbon due to incomplete filling of sucrose to the template pore channels and/or (2) the shrinkage of zeolite-carbon during the carbonization due to the oxygen rich of sucrose resulting in the large amount of gaseous species such as $\mathrm{CO}_{2}$ and $\mathrm{H}_{2} \mathrm{O}$ [12,33-34]. Furthermore, we have used HK method by assuming slit pore geometry to evaluate micropore size (below $2 \mathrm{~nm}$ ) distribution and $\mathrm{BJH}$ method to analyze the mesopores above $2 \mathrm{~nm}$ of the zeolite-Y and ZTC, as shown in Fig. 7(b) and (c). It can be seen that the as-synthesized ZTC exhibits a sharp peak around 0.7-1.5 nm (Fig. 7(b)), indicating the presence of micropores of the ZTC and the size distribution of the ZTC is sharper than the zeolite-Y. In addition, the $\mathrm{BJH}$ method (Fig. 7(c)) confirms the presence of mesopores in the ZTC around 3-23 nm. The mesopores were attributed to the amorphous graphitic carbon, covering the ZTC particles. The BET surface area, total pore volume and micropore volume of ZTC in this study were $932 \mathrm{~m}^{2} / \mathrm{g}, 0.97 \mathrm{~cm}^{3} / \mathrm{g}$, and $0.3 \mathrm{~cm}^{3} / \mathrm{g}$, respectively. Konwar and De [29] also reported the ZTC synthesis materials with zeolite- $\mathrm{Y}$ and sucrose, the highest BET surface area, total pore volume, and micropore volume were $1033 \mathrm{~m}^{2} / \mathrm{g}, 0.676 \mathrm{~cm}^{3} / \mathrm{g}$, and $0.293 \mathrm{~cm}^{3} / \mathrm{g}$, respectively, which were close to the value in this study. However, better properties of sucrose-based carbon via template method using zeolite- $\mathrm{Y}$ was achieved from another study [13].

\section{Hydrogen Adsorption Study of ZTC}

The process of hydrogen adsorption on carbons is governed by physisorption and preferably occurs at a lower temperature [34-35]. However, it is greatly desirable for adsorbent materials that adsorb hydrogen at or near room temperature for its application to meet the DOE target for the hydrogen storage system.

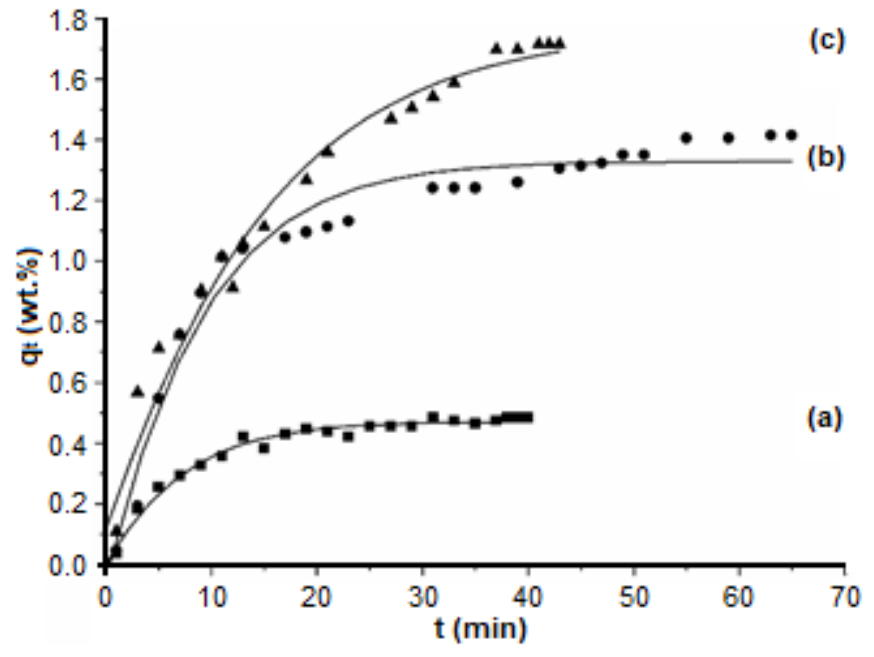

Fig 8. Adsorption capacity with adsorption time at various temperature measured gravimetrically (a) 30 , (b) 40 and (d) $50^{\circ} \mathrm{C}$

The hydrogen uptake measured gravimetrically at different temperature of 30,40 and $50{ }^{\circ} \mathrm{C}$ and pressure of 1 bar (Fig. 8) were studied in the present work. Highest hydrogen sorption was obtained at the lowest temperature of $30^{\circ} \mathrm{C}$ with $1.72 \mathrm{wt} . \%$ storage. It could be occurred since physically adsorption take places in the interaction between hydrogen molecules and carbon material on van der Waals force. At low temperature, the thermal motion energy of hydrogen was in accordance with the van der Waals force, leading to the stronger interaction [36]. The electronegativity between carbon and hydrogen as an atom has a low range, and therefore, the bonding has a weak dipole moment and keep their characteristics when the adsorption process occurs. Comparing the adsorption of ZTC with data available in the previous literature is presented in Table 2. In this study, the hydrogen adsorption capacities were quite low. It could be attributed with a low quantity of micropore volume, resulting to the low interaction energy between pore walls and hydrogen molecules in the narrower pores and less accessible adsorption sites for hydrogen molecules [19].

In order to confirm the hydrogen sorption gravimetrically, adsorption was also conducted using the volumetric determination of the prepared ZTC. The hydrogen uptake capacities performed by the volumetric method were $5.81,5.68$ and $5.64 \mathrm{mmol} / \mathrm{g}$ or equal to 1.16 , 
Table 2. Physical properties and hydrogen adsorption capacity for different carbon-based materials

\begin{tabular}{|c|c|c|c|c|c|c|c|c|}
\hline \multirow[b]{2}{*}{ Carbon source } & \multirow[b]{2}{*}{$\begin{array}{l}\text { Zeolite } \\
\text { template }\end{array}$} & \multirow[b]{2}{*}{$\begin{array}{l}\text { Preparation } \\
\text { method }\end{array}$} & \multicolumn{3}{|c|}{ Textural properties } & \multirow[b]{2}{*}{$\begin{array}{l}\text { Hydrogen } \\
\text { uptake } \\
\text { (wt.\%) }\end{array}$} & \multirow[b]{2}{*}{$\begin{array}{l}\text { Temperature } \\
\left({ }^{\circ} \mathrm{C}\right) \text { and pressure } \\
\text { (bar) adsorption }\end{array}$} & \multirow[b]{2}{*}{ Ref. } \\
\hline & & & $\begin{array}{l}\text { Specific } \\
\text { surface } \\
\text { area }\left(\mathrm{m}^{2} / \mathrm{g}\right)\end{array}$ & $\begin{array}{l}\text { Micropore } \\
\text { volume } \\
\left(\mathrm{cm}^{3} / \mathrm{g}\right)\end{array}$ & $\begin{array}{l}\text { Mesopore } \\
\text { volume } \\
\left(\mathrm{cm}^{3} / \mathrm{g}\right)\end{array}$ & & & \\
\hline Sucrose & $\begin{array}{l}\text { USY } \\
\text { zeolite }\end{array}$ & Carbonization & $701-1219$ & $0.30-0.5$ & $0.09-0.61$ & $1.15-1.43^{\mathrm{a}}$ & $-196 ; 1$ & {$[19]$} \\
\hline Sucrose & $\begin{array}{l}\mathrm{NH}_{4} \mathrm{Y} \\
\text { zeolite }\end{array}$ & Carbonization & $684-1033$ & $0.21-0.29$ & $0.20-0.38$ & $0.25-0.30^{\mathrm{b}}$ & $-100 ; 1$ & {$[29]$} \\
\hline Furfuryl alcohol & $\begin{array}{l}\mathrm{NH}_{4} \mathrm{Y} \\
\text { zeolite }\end{array}$ & Carbonization & 1886 & $0.01-0.51$ & $0.07-0.80$ & $0.08-0.29^{\mathrm{b}}$ & $-100 ; 1$ & {$[7]$} \\
\hline Sucrose & $\begin{array}{l}\mathrm{NH}_{4} \mathrm{Y} \\
\text { zeolite }\end{array}$ & Carbonization & 1500 & 0.78 & 0.52 & $2.4^{\mathrm{c}}$ & $-196 ; 10$ & {$[13]$} \\
\hline $\begin{array}{l}\text { Propylene and } \\
\text { butylene }\end{array}$ & $\begin{array}{l}\text { Zeolite- } \\
\mathrm{Y}\end{array}$ & CVD & $1040-2470$ & $0.43-1.05$ & $0.27-0.47$ & $0.8-2.0^{\mathrm{a}}$ & $-196 ; 1$ & {$[11]$} \\
\hline $\begin{array}{l}\text { Furfuryl alcohol- } \\
\text { acetylene }\end{array}$ & $\begin{array}{l}\text { Zeolite- } \\
10 \mathrm{X}\end{array}$ & CVD & $1303-3331$ & $0.33-1.00$ & $0.55-0.94$ & $1.09-2.27^{\mathrm{a}}$ & $-196 ; 1$ & {$[34]$} \\
\hline Sucrose & $\begin{array}{l}\text { Zeolite- } \\
\mathrm{Y}\end{array}$ & Carbonization & 932 & 0.30 & 0.67 & $\begin{array}{l}0.48-1.72^{\mathrm{a}} \\
1.10-1.14^{\mathrm{c}}\end{array}$ & $\begin{array}{l}30-50 ; 1 \\
30-50 ; 2\end{array}$ & $\begin{array}{l}\text { This } \\
\text { study }\end{array}$ \\
\hline
\end{tabular}

${ }^{a}$ Hydrogen uptake is measured via gravimetric adsorption method

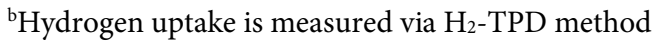

${ }^{c}$ Hydrogen uptake is measured via volumetric method

1.14 and 1.12 wt. $\%$ at 30,40 and $50^{\circ} \mathrm{C}\left( \pm 3{ }^{\circ} \mathrm{C}\right)$ and 2 bars, respectively. A slightly different result of the hydrogen adsorption capacity obtained between the two techniques due to a small difference in operating pressure. At low pressure, hydrogen prefers to occupy the position at the adsorbate-pore interaction. Therefore, the density of hydrogen is highest in the smaller pores (micropores) [37]. At a temperature of 30,40 and $50{ }^{\circ} \mathrm{C}$, this calculated hydrogen adsorption capacity is equal to a volumetric density of $17.43,17.04$ and $16.92 \mathrm{~g} / \mathrm{L}$, respectively. Furthermore, the volumetric density values reported in this study were much lower to the ultimate DOE target of $70 \mathrm{~g} / \mathrm{L}$. The performance of adsorption can be improved on the control of the surface area and micropore volume via synthesis conditions. Another attempt of improving the hydrogen capacity is chemically surface modification of carbon to enhance the interaction with hydrogen.

\section{Adsorption Kinetics Study}

In order to determine the adsorption mechanism, the kinetic study of hydrogen adsorption would be indispensable. Three kinetic models in terms of pseudo- first and second order, as well as intra particle diffusion model, were tested to fit with experimental data.

\section{Pseudo first order model}

This equation is proposed to explain unsteady state adsorption in porous material [38]. The pseudo first order kinetic plots between $\mathrm{t}$ and $\ln \left(\mathrm{q}_{\mathrm{e}}-\mathrm{q}_{\mathrm{t}}\right)$ of hydrogen sorption at 30,40 and $50^{\circ} \mathrm{C}$ by ZTC were presented in Fig. 9. The parameter values calculated from fitting the

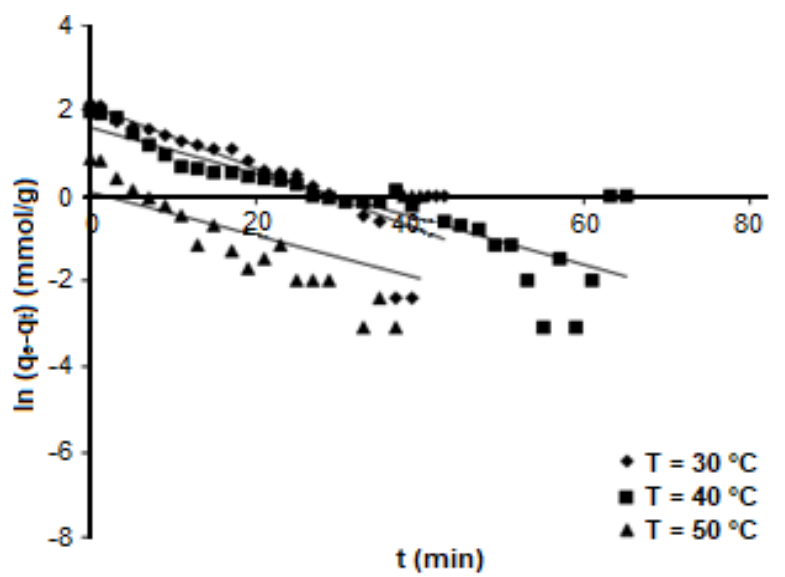

Fig 9. Pseudo first order kinetic plots for hydrogen adsorption onto ZTC at 30,40 , and $50^{\circ} \mathrm{C}$ 
experimental data are summarized in Table 3. As can be seen, the increasing temperature at constant pressure leads to a lower rate constant $\mathrm{k}_{\mathrm{f}}$ value. This showed that $\mathrm{a}$ lower temperature leads to a higher amount of hydrogen adsorbed. For all samples, the correlation coefficients $\left(\mathrm{R}^{2}\right)$ for this kinetic model were clearly poor. It was also observed that the calculated adsorption capacities $\left(\mathrm{q}_{\mathrm{e}}\right)$ at three samples deviated to the experimental values in Fig. 8. These indicate that the adsorption mechanism of hydrogen into ZTC could not be characterized by this kinetic model.

\section{Pseudo second-order model}

This kinetic model is assumed that linearity exists between adsorption capacity with the presence of active sites in adsorbent [39]. Fig. 10 showed the slope and intercept plots of time $t$ and adsorbed capacity $\mathrm{q}_{\mathrm{t}}$, while the values were presented in Table 3 . It showed a higher adsorption rate for a lower temperature and the correlation coefficient $\left(R^{2}\right)$ values calculated were well at the whole condition. The calculated adsorption capacities were also close to the experimental data in Fig. 8. It can be summarized that the hydrogen adsorption process at all studied temperatures were best approximated to this kinetic model.

\section{Intra particle diffusion model}

In this study, this model is used to identify diffusion for adsorption process. By plotting of $\mathrm{q}_{\mathrm{t}}$ versus $\mathrm{t}^{0.5}$ in Fig.

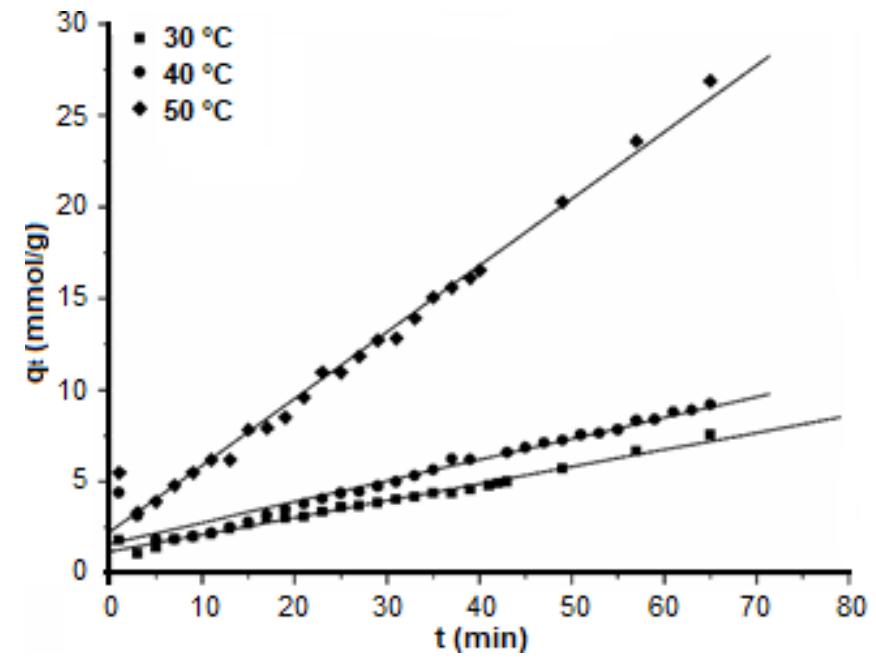

Fig 10. Pseudo second order kinetic plots for hydrogen adsorption by ZTC at 30,40 , and $50^{\circ} \mathrm{C}$
11 , the $\mathrm{q}_{\mathrm{e}}$ and the rate constant values can be calculated. Such plots showed double linearity region that indicates two steps of the adsorption process. The first step line is attributed to the hydrogen diffusion through an external surface or boundary layer of ZTC, and the other line relates to the internal surface diffusion (micropore or mesopore diffusion). During the adsorption process, hydrogen diffusion was very fast in the early step and subsequently slow diffusion over the internal surface (Fig. 11).

Table 3. Kinetic parameters for hydrogen adsorption at three kinetic models

\begin{tabular}{|c|c|c|c|}
\hline Kinetic models & Parameters & & \\
\hline \multicolumn{4}{|c|}{ Pseudo-first-order } \\
\hline Temperature $\left({ }^{\circ} \mathrm{C}\right)$ & $\mathrm{q}_{\mathrm{e}}(\mathrm{mmol} / \mathrm{g})$ & $\mathrm{k}_{\mathrm{f}}\left(\mathrm{min}^{-1}\right)$ & $\mathrm{R}^{2}$ \\
\hline 30 & 8.01 & 0.09 & 0.72 \\
\hline 40 & 4.86 & 0.05 & 0.72 \\
\hline 50 & 2.30 & 0.05 & 0.32 \\
\hline \multicolumn{4}{|c|}{ Pseudo-second-order } \\
\hline Temperature $\left({ }^{\circ} \mathrm{C}\right)$ & $\mathrm{k}_{\mathrm{s}}(\mathrm{mmol} / \mathrm{g} \min )$ & $\mathrm{q}_{\mathrm{e}}(\mathrm{mmol} / \mathrm{g})$ & $\mathrm{R}^{2}$ \\
\hline 30 & 0.97 & 10.34 & 0.97 \\
\hline 40 & 0.71 & 8.45 & 0.93 \\
\hline 50 & 0.51 & 2.69 & 0.98 \\
\hline \multicolumn{4}{|c|}{ Intra particle diffusion } \\
\hline Temperature $\left({ }^{\circ} \mathrm{C}\right)$ & $\mathrm{k}_{\mathrm{id}}\left(\mathrm{mmol} / \mathrm{g} \mathrm{min} \mathrm{min}^{0.5}\right)$ & $\mathrm{R}^{2}$ & \\
\hline 30 & 1.20 & 0.94 & \\
\hline 40 & 0.83 & 0.86 & \\
\hline 50 & 0.31 & 0.81 & \\
\hline
\end{tabular}

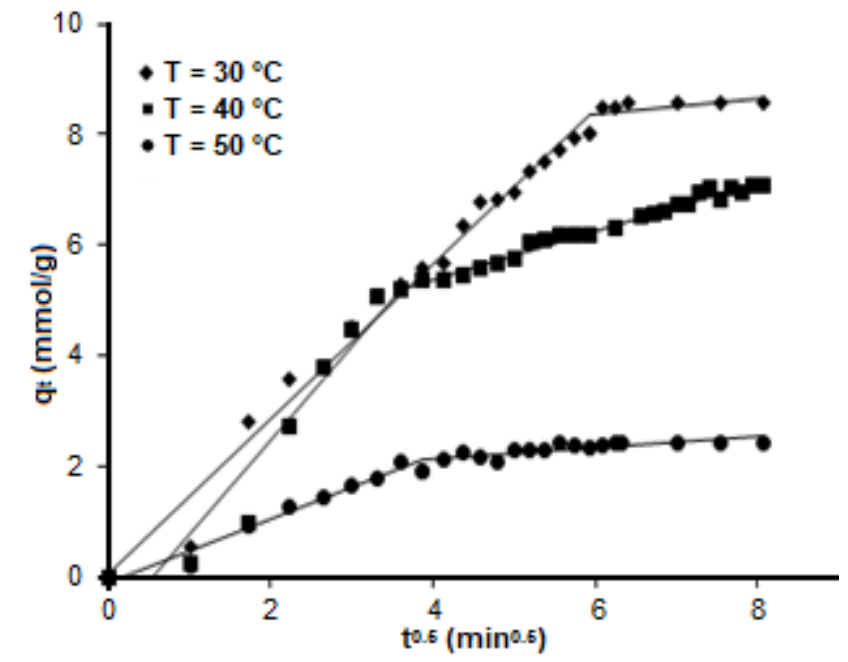

Fig 11. Intraparticle diffusion plots for hydrogen adsorption by ZTC at 30,40 , and $50^{\circ} \mathrm{C}$ 
Table 4. Thermodynamic parameters for hydrogen adsorption onto zeolite templated carbon

\begin{tabular}{llcc}
\hline $\mathrm{T}\left({ }^{\circ} \mathrm{C}\right)$ & $\Delta \mathrm{G}\left(\mathrm{kJ} \mathrm{mol}^{-1}\right)$ & $\Delta \mathrm{H}\left(\mathrm{kJ} \mathrm{mol}^{-1}\right)$ & $\Delta \mathrm{S}_{\mathrm{H}}\left(\mathrm{J} \mathrm{K}^{-1} \mathrm{~mol}^{-1}\right)$ \\
\hline 30 & -1.99 & & \\
40 & -1.59 & -14.41 & -40.93 \\
50 & -1.19 & & \\
\hline
\end{tabular}

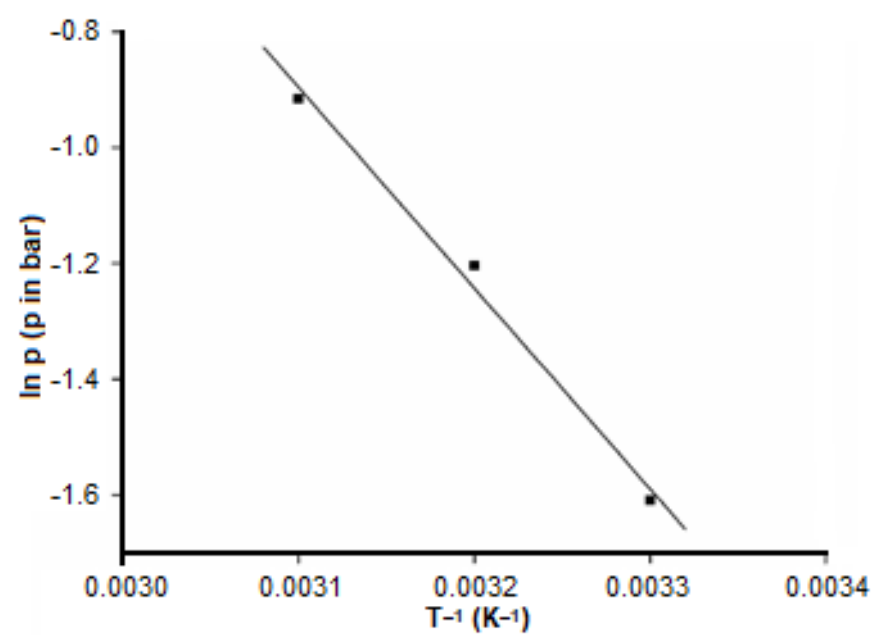

Fig 12. Enthalpy of adsorption of hydrogen onto the ZTC

\section{Thermodynamic Studies}

The thermodynamic aspects (Fig. 12) provide a conceptual insight of the adsorption mechanism of the adsorption process. As presented in Table 4 , the $\Delta \mathrm{G}$ and $\Delta \mathrm{H}$ values were negative which indicate a spontaneous and exothermic process, respectively [40]. The $\Delta \mathrm{H}$ value obtained was much smaller than $80 \mathrm{~kJ} \mathrm{~mol}^{-1}$ $\left(14.41 \mathrm{~kJ} \mathrm{~mol}^{-1}\right)$, indicating a physical adsorption process of hydrogen into ZTC [22,26]. Such $\Delta H$ value was significantly larger than that shown by other studies $[12,18]$. The material which is able to adsorp the hydrogen at room temperature possess a heat of adsorption change value of $15.1 \mathrm{~kJ} / \mathrm{mol}$, which is very close with the value in this study [23]. The small of $\Delta \mathrm{G}$ value together with the high temperature revealed that the adsorption is more efficient or spontaneous at a lower temperature. Small randomness in the interface of ZTC and hydrogen during the adsorption process was revealed by the negative value of $\Delta \mathrm{S}_{\mathrm{H}}\left(-40.93 \mathrm{~J} \mathrm{~K}^{-1} \mathrm{~mol}^{-1}\right)$.

\section{- CONCLUSION}

In summary, a zeolite templated carbon (ZTC) was successfully synthesized via carbonization and investigated their hydrogen uptake properties. Such material is principally amorphous with a surface area of $932 \mathrm{~m}^{2} / \mathrm{g}$, total pore volume of $0.97 \mathrm{~cm}^{3} / \mathrm{g}$ and exhibits well pore ordering structure derived from the template as well as some graphitic carbon. The ZTC obtained was tested for hydrogen storage at a temperature of $30-50^{\circ} \mathrm{C}$ and its capacity was greatly dependent with temperature condition. Greater hydrogen uptake was observed at lower temperature and pressure of 1 bar as high as 1.72 wt.\%. This value was close to the calculated adsorption capacity by volumetric method as high as $1.16 \mathrm{wt} . \%$ at 2 bar, similar to a volumetric density of $17.43 \mathrm{~g} \mathrm{H}_{2} / \mathrm{L}$. The calculated value here was much lower to the ultimate DOE target of $7.5 \mathrm{wt} . \%$ and $70 \mathrm{~g} \mathrm{H}_{2} / \mathrm{L}$. Therefore, preparing method here should be improved to obtain a significant proportion of micropores or even ultramicropores, which is contributed to higher $\mathrm{H}_{2}$ uptake. The kinetic models showed that pseudo second order kinetic model best fitted for all adsorption condition. The thermodynamic aspects such as enthalpy and entropy change were $14.41 \mathrm{~kJ} \mathrm{~mol}^{-1}$ and $-40.93 \mathrm{~J} \mathrm{~K}^{-1} \mathrm{~mol}^{-1}$, respectively. A small value of the enthalpy described the physical adsorption process and found to be exothermic as confirmed by a negative sign of the enthalpy. The change of entropy was negative indicating decreasing randomness at the ZTC and hydrogen interface during physisorption process. The process occurred spontaneously as indicated by the negative Gibbs free energy change values. This value decreased by high temperature, indicating less effective of the adsorption process.

According to the results above, it can be said that ZTC is an attractive material for hydrogen storage and deserves further study in order to achieve better performance of adsorption.

\section{- ACKNOWLEDGMENTS}

The authors are grateful to the Directorate General of Higher Education, Ministry of Research, Technology and Higher Education of Republic of Indonesia for providing financial support under PMDSU scholarship for doctoral degree for Rika Wijiyanti and Triyanda Gunawan, and also the research funding under 
"Program Penelitian Magister Doktor Sarjana Unggul (PMDSU)” (No: 135/SP2H/LT/DRPM/IV/2017).

\section{- REFERENCES}

[1] Xia, Y., Yang, Z., and Zhu, Y., 2013, Porous carbonbased materials for hydrogen storage: Advancement and challenges, J. Mater. Chem. A, 1 (33), 9365-9381.

[2] Hydrogen Storage Technical Team, 2017, Hydrogen Storage Technical Team Roadmap, United States Department of Energy.

[3] Krishna, R., Titus, E., Salimian, M., Okhay, O., Rajendran, S., Rajkumar, A., Sousa, J.M.G., Ferreira, A.L.C., Gil, J.C., and Gracio, J., 2012, "Hydrogen Storage for Energy Application" in Hydrogen Storage, Eds., Liu, J., IntechOpen, London, 243-266.

[4] Tedds, S., Walton, A., Broom, D.P., and Book, D., 2011, Characterisation of porous hydrogen storage materials: Carbons, zeolites, MOFs and PIMs, Faraday Discuss., 151, 75-94.

[5] Nijkamp, M.G., Raaymakers, J.E.M.J., van Dillen, A.J., and de Jong, K.P., 2001, Hydrogen storage using physisorption-materials demands, Appl. Phys. A, 72 (5), 619-623.

[6] Zubizarreta, L., Arenillas, A., and Pis, J.J., 2009, Carbon materials for $\mathrm{H}_{2}$ storage, Int. J. Hydrogen Energy, 34 (10), 4575-4581.

[7] Konwar, R.J., and De, M., 2013, Effects of synthesis parameters on zeolite templated carbon for hydrogen storage application, Microporous Mesoporous Mater., $175,16-24$.

[8] Darkrim, F.L., Malbrunot, P., and Tartaglia, G.P., 2002, Review of hydrogen storage by adsorption in carbon nanotubes, Int. J. Hydrogen Energy, 27 (2), 193-202.

[9] Armandi, M., Bonelli, B., Areán, C.O., and Garrone, E., 2008, Role of microporosity in hydrogen adsorption on templated nanoporous carbons, Microporous Mesoporous Mater., 112 (1-3), 411-418.

[10] Dong, J., Wang, X., Xu, H., Zhao, Q., and Li, J., 2007, Hydrogen storage in several microporous zeolites, Int. J. Hydrogen Energy, 32 (18), 4998-5004.

[11] Chen, L., Singh, R.K., and Webley, P., 2007, Synthesis, characterization and hydrogen storage properties of microporous carbons templated by cation exchanged forms of zeolite $\mathrm{Y}$ with propylene and butylene as carbon precursors, Microporous Mesoporous Mater., 102 (1-3), 159-170.

[12] Yang, Z., Xia, Y., and Mokaya, R., 2007, Enhanced hydrogen storage capacity of high surface area zeolite-like carbon materials, J. Am. Chem. Soc., 129 (6), 1673-1679.

[13] Guan, C., Wang, K., Yang, C., and Zhao, X.S., 2009, Characterization of a zeolite-templated carbon for $\mathrm{H}_{2}$ storage application, Microporous Mesoporous Mater., 118 (1-3), 503-507.

[14] Song, X.H., Xu, R., and Wang, K., 2013, The structural development of zeolite-templated carbon under pyrolysis, J. Anal. Appl. Pyrolysis, 100, 153-157.

[15] Kyotani, T., Ma, Z., and Tomita, A., 2003, Template synthesis of novel porous carbons using various types of zeolites, Carbon, 41 (7), 1451-1459.

[16] Böhme, K., Einicke, W., and Klepel, O., 2005, Templated synthesis of mesoporous carbon from sucrose-the way from the silica pore filling to the carbon material, Carbon, 43 (9), 1918-1925.

[17] Yang, Z., Xia, Y., Sun, X., and Mokaya, R., 2006, Preparation and hydrogen storage properties of zeolite-templated carbon materials nanocast via chemical vapor deposition: Effect of the zeolite template and nitrogen doping, J. Phys. Chem. B, 110 (37), 18424-18431.

[18] Johnson, S.A., Brigham, E.S., Ollivier, P.J., and Mallouk, T.E., 1997, Effect of micropore topology on the structure and properties of zeolite polymer replicas, Chem. Mater., 9 (11), 2448-2458.

[19] Cai, J., Yang, M., Xing, Y., and Zhao, X., 2014, Large surface area sucrose-based carbons via templateassisted routes: Preparation, microstructure, and hydrogen adsorption properties, Colloids Surf., A, 444, 240-245.

[20] Nishihara, H., Hou, P.X., Li, L.X., Ito, M., Uchiyama, M., Kaburagi, T., Ikura, A., Katamura, J., Kawarada, T., Mizuuchi, K., and Kyotani, T., 2009, High-pressure hydrogen storage in zeolitetemplated carbon, J. Phys. Chem. C, 113 (8), 31893196. 
[21] Hirscher, M., and Becher, M., 2003, Hydrogen storage in carbon nanotubes, J. Nanosci. Nanotechnol., 3 (12), 3-17.

[22] Zamora, B., Al-Hajjaj, A.A., Shah, A.A., Bavykin, D.V., and Reguera, E., 2013, Kinetic and thermodynamic studies of hydrogen adsorption on titanate nanotubes decorated with a Prussian blue analogue, Int. J. Hydrogen Energy, 38 (15), 6406-6416.

[23] Bhatia, S.K., and Myers, A.L., 2006, Optimum conditions for adsorptive storage, Langmuir, 22 (4), 1688-1700.

[24] Synthesis Commission of the International Zeolite Association, 2016, Verified Syntheses of Zeolitic Materials, Eds., Mintova, S., International Zeolite Association.

[25] Luo, J., Liu, Y., Jiang, C., Chu, W., Jie, W., and Xie, H., 2011, Experimental and modeling study of methane adsorption on activated carbon derived from anthracite, J. Chem. Eng. Data, 56 (12), 4919-4926.

[26] Khalili, S., Ghoreyshi, A.A., and Jahanshahi, M., 2012, Carbon dioxide captured by multi-walled carbon nanotube and activated charcoal: A comparative study, Chem. Ind. Chem. Eng. Q., 19 (1), 153-164.

[27] Widiastuti, N., Wu, H., Ang, H.M., and Zhang, D., 2011, Removal of ammonium from greywater using natural zeolite, Desalination, 277 (1-3), 15-23.

[28] Su, F., Zhao, X.S., Lv, L., and Zhou, Z., 2004, Synthesis and characterization of microporous carbons templated by ammonium-form zeolite Y, Carbon, 42 (14), 2821-2831.

[29] Konwar, R.J., and De, M., 2015, Development of templated carbon by carbonisation of sucrose-zeolite composite for hydrogen storage, Int. J. Energy Res., 39 (2), 223-233.

[30] Nishihara, H., and Kyotani, T., 2012, "ZeoliteTemplated Carbon - Its Unique Characteristics and Applications" in Novel Carbon Adsorbents, Eds., Tascón, J.M.D., Elsevier Ltd, Amsterdam, 295-322.

[31] Greer, H.F., and Zhou, W., 2011, Electron diffraction and HRTEM imaging of beam-sensitive materials, Crystallogr. Rev., 17 (3), 163-185.

[32] Choi, S., Kim, H., Lee, S., Wang, Y., Ercan, C., Othman, R., and Choi, M., 2015, Large-scale synthesis of high-quality zeolite-templated carbons without depositing external carbon layers, Chem. Eng. J., 280, 597-605.

[33] Ma, Z., Kyotani, T., and Tomita, A., 2002, Synthesis methods for preparing microporous carbons with a structural regularity of zeolite Y, Carbon, 40 (13), 2367-2374.

[34] Cai, J., Li, L., Lv, X., Yang, C., and Zhao, X., 2014, Large surface area ordered porous carbons via nanocasting zeolite 10x and high performance for hydrogen storage application, ACS Appl. Mater. Interfaces, 6 (1), 167-175.

[35] Saha, D., Wei, Z., and Deng, S., 2008, Equilibrium, kinetics and enthalpy of hydrogen adsorption in MOF-177, Int. J. Hydrogen Energy, 33 (24), 74797488.

[36] Jin, H., Lee, Y.S., and Hong, I., 2007, Hydrogen adsorption characteristics of activated carbon, Catal. Today, 120 (3-4), 399-406.

[37] Bonenfant, D., Kharoune, M., Niquette, P., Mimeault, M., and Hausler, R., 2008, Advances in principal factors influencing carbon dioxide adsorption on zeolites, Sci. Technol. Adv. Mater., 9 (1), 013007.

[38] Delavar, M., Asghar Ghoreyshi, A., Jahanshahi, M., Khalili, S., and Nabian, N., 2012, Equilibria and kinetics of natural gas adsorption on multi-walled carbon nanotube material, RSC Adv., 2 (10), 44904497.

[39] Ho, Y.S., and McKay, G., 1999, Pseudo-second order model for sorption processes, Process Biochem., 34 (5), 451-465.

[40] Rodrigues, L.A., and da Silva, M.L.C.P., 2010, Thermodynamic and kinetic investigations of phosphate adsorption onto hydrous niobium oxide prepared by homogeneous solution method, Desalination, 263 (1-3), 29-35. 